\title{
Modelling Global Wolfram Mining, Secondary Extraction, Supply, Stocks-in-Society, Recycling, Market Price and Resources, Using the WORLD6 System Dynamics Model
}

\author{
Harald Ulrik Sverdrup ${ }^{1}$ (i) $\cdot$ Anna Hulda Olafsdottir ${ }^{1} \cdot$ Kristin Vala Ragnarsdottir $^{2}$
}

Received: 10 April 2017 / Accepted: 11 July 2017 / Published online: 7 August 2017

(c) Springer International Publishing AG 2017

\begin{abstract}
The extraction, supply, market price and recycling of the metal wolfram (W) were modelled using a wolfram submodule developed for the WORLD6 system dynamics model. The resource estimates made for wolfram resulted in significantly larger estimates than earlier studies (URR $=28$ million ton in 2015, where at least 24 million ton is in primary ore and about 2 million ton is secondary resources). The model can well reconstruct the observed extraction rates and price histories. The model outputs demonstrate that wolfram is a finite resource and that there is a risk for supply scarcity, unless the degree of recycling will be significantly improved from the present level. The model outputs suggest that there will be a soft scarcity around 2030 and hard scarcity after 2200 . When pictured as supply per person per year or stocks-in-use, there will be a supply problem in the distant future. There are substitutes for some applications, but for some key uses there are none that are optimal. Without wolfram, several advanced technologies seen as important at the present time will become difficult to produce.
\end{abstract}

Keywords Wolfram $\cdot$ System dynamics $\cdot$ Mining · Extraction $\cdot$ Tungsten

Harald Ulrik Sverdrup

hus@hi.is

1 Industrial Engineering, University of Iceland, Hjarðarhagi 2-6, 107 Reykjavik, Iceland

2 Institute of Earth Sciences, University of Iceland, Askja, 101 Reykjavik, Iceland

\section{Introduction}

The authors have built a global resource supply model referred to as WORLD6, assessing long-term sustainability of all major metals, materials and energy sources, in a way where they are interactively linked. This study shows the global wolfram (W) supply and recycling. Wolfram is a useful metal with interesting technological properties, but is produced in relatively limited amounts. The wolfram market price is high, and it is not used in any large amounts for mass markets.

\section{Objectives and Scope}

The goal of this research was to develop a model for the production and cycling of wolfram in society and to include this as a module in the WORLD system dynamics model. The most significant uses for wolfram are for hard cutting tool bits and for specialty alloys. The objective of this study is to use the validated system dynamics model to explore how to make the global wolfram supply system more sustainable. The consumer side of wolfram use is not yet developed in WORLD6, but it will follow in later studies.

\section{The Element Wolfram (W)}

Wolfram is an exotic metal that is presently used in hightechnology and sophisticated metallurgy. Wolfram is known as tungsten in most English-speaking countries, but outside the English-speaking world the metal name is wolfram, and that is the recognized official name for the element by the International Union of Pure and Applied Chemistry (IUPAC). Thus, we use wolfram instead of tungsten in this study. In 1759, the Swedish chemist Axel Fredrik Cronstedt (Fig. 1) discovered an unusual mineral he called "tungsten" 
Fig. 1 Axel Fredrik Cronstedt

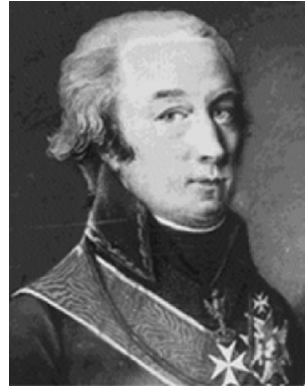

Fig. 2 Carl Wilhelm Scheele

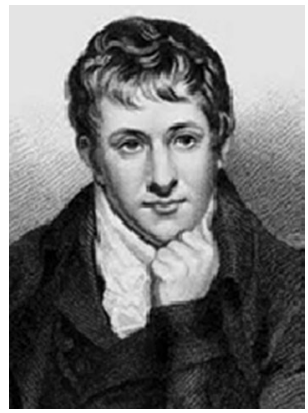

("heavy stone" in Swedish) and was convinced it contained a new element. But he had trouble isolating it. The element was recognized in 1781 by the Swedish scientist Carl Wilhelm Scheele in Uppsala (Scheele 1781, Fig. 2) and who isolated the metal in 1783. The same year, the Spanish brothers Fausto and Juan José Elhuyar de Suvisa rediscovered the element and obtained the international recognition for it.

Wolfram is the metal with the highest melting point of all metals $\left(3422^{\circ} \mathrm{C}\right)$, and it can be used to produce very hard alloys and carbides. Its specific density is almost the same as that of gold. The dominating use is in hard cutting tools (61\%), special metallic alloys $(20 \%)$, tube, wire and plate (11.4\%) and some chemicals (7.3\%). Wolfram is also important for military armament and heavy armourpiercing ordinance. Figure 3 shows the world production of wolfram and the market price. China is the dominating wolfram producer at the present moment $(83 \%$ of the global extraction), but their reserves and resources are modest. The market price shows very distinct pattern of volatile price changes. The main wolfram ores are scheelite $\left(\mathrm{CaWO}_{4}\right)$ with about $30 \%$ of the supply and wolframite $\left(\mathrm{FeWO}_{4}\right)$ with about $70 \%$ of the total supply. Secondary extraction is marginal for wolfram $(5-6 \%)$ but increasing; secondary production from tin is about $4 \%$ of the total, with small contributions from copper, zinc, tantalum and niobium mining. Recycling is significant (35-40\%) and could increase.

In the US Geological Survey estimate for 2014, the wolfram reserves are reported to be about 9 million ton of wolfram, up from 3.3 million ton of wolfram a few years earlier. Reserves are the known and proven reserves, omitting that there may be more wolfram deeper in the deposits that are not yet found. We use the terms "known" in our classification (reserves) and "hidden" (resources that are there, but yet not found). "Known" and "hidden" make up the total extractable resources. Resources are defined as the total amount that can in due time be found and extracted, even if some or much of it would require a higher price and more exploiting effort. But technically the wolfram will sooner or later be available, provided that we will make effort to extract it. The types of deposits being mined at present and their sizes are shown in Table 1. In some large and thinly populated areas such as Greenland, Canada, Russia or Brazil, only a fraction of the area has been prospected, and the wolfram resources may be significantly larger. This is only partly reflected in our estimate of yet undiscovered wolfram in Table 1. Wolfram could be supplied from many countries that do not at present mine any wolfram resources
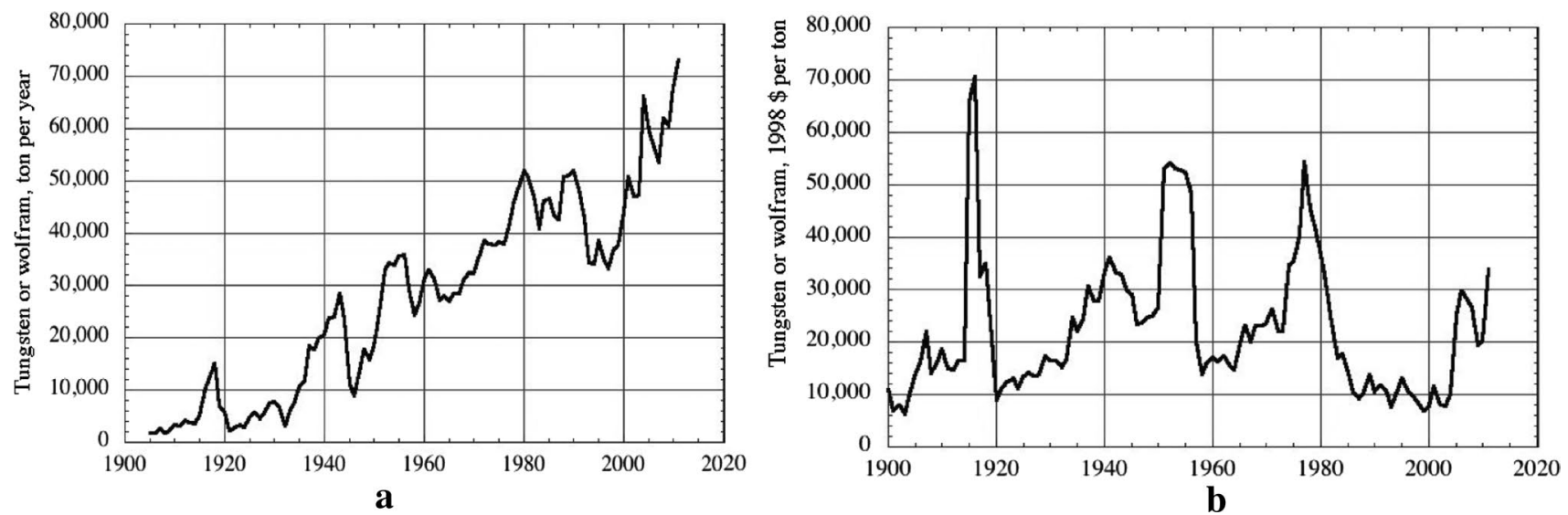

Fig. 3 The world production of wolfram (a) and the market price (b). The market price shows very distinct cyclic pattern of price changes 
Table 1 Wolfram production, reserves and resources in several countries

\begin{tabular}{lllll}
\hline Country & Extraction & \multicolumn{3}{l}{ Million ton of wolfram } \\
\cline { 3 - 5 } & Ton wolfram per year & $\begin{array}{l}\text { Reserves } \\
\text { (known) }\end{array}$ & $\begin{array}{l}\text { Resources } \\
\text { (hidden) }\end{array}$ & Total \\
\hline Rwanda & 1000 & 0.650 & 0.300 & 0.950 \\
Congo & 800 & 0.500 & 0.800 & 1.300 \\
China & 71,000 & 1.900 & 5.000 & 6.900 \\
Brazil & - & 0.055 & 0.800 & 0.855 \\
Australia & 600 & 0.200 & 0.400 & 0.600 \\
Canada & 3000 & 0.290 & 1.200 & 1.490 \\
USA & - & 0.100 & 1.000 & 1.100 \\
Kazakhstan & - & 0.300 & 3.500 & 3.800 \\
Vietnam & 5000 & 0.100 & 1.800 & 1.900 \\
Bolivia & 1300 & 0.053 & 0.120 & 0.173 \\
Portugal & 630 & 0.004 & 0.050 & 0.054 \\
Spain & 730 & 0.005 & 0.015 & 0.020 \\
Austria & 870 & 0.010 & 0.058 & 0.068 \\
Britain & 600 & 0.050 & 0.150 & 0.020 \\
Russia & 2800 & 0.250 & 3.800 & 4.150 \\
Others & 250 & 1.200 & 2.100 & 3.300 \\
Undiscovered & - & 3.000 & 4.000 & 7.000 \\
Sum & 88,500 & 9.212 & 18.330 & 27.542 \\
\hline & & & & \\
& & & &
\end{tabular}

Numbers in italics are our own estimates from corporate information where published estimates are failing

of their own, but which may do that if the wolfram price increases somewhat from the present level. Many of these countries have smelter capacity and purchase their ore in the markets. $35 \%$ of all wolfram is recycled at present, and this can increase. In nature, tin and wolfram tend to coexist in deposits for geochemical reasons and because they both have a high specific density and are therefore enriched by gravimetric processes (placer ores).

Wolfram has important use as a component of superalloys, mainly for increasing the melting point and the alloy hardness. Typically, wolfram ores contain traces of As, Bi, Sn, Ti, Hf, Sc, REE, V, Pb, Zn, Zr, Ta, Nb, Th and U (Lehmann et al. 2014). Wolfram is also present in polymetallic ores, which contain more wolfram (4 million ton) than primary wolfram ores (about 20 million ton). Before 2015, about 3-3.4 million ton of wolfram had been extracted. A simple flow chart for the extraction of wolfram is shown in Fig. 4. In the WORLD6 model, the flow chart structure shown in Fig. 6 was used.

\section{Methods and Theory Used}

\section{Modelling}

The core method used to develop the integrated model is systems analysis and systems dynamics (Sterman 2000; Senge 1990). The method was selected because it is able to grasp the market dynamics and the feedbacks known to be present in the real global mining and metal trading systems (Daigo et al. 2010). It is important that the links are true causal links and not based on correlations or modelled on a chain of events. The causal loop diagram (see Fig. 5) maps all significant causal connections in the system. The system was analysed using flow charts (Figs. 4, 6) based on boxarrow symbols, causal loop diagrams (Figs. 5, 7) defining the mass balance expressed as differential equations and numerically solved using the STELLA ${ }^{\circledR}$ system dynamics software (Senge 1990; Sterman 2000; Haraldsson and Sverdrup 2004; Sverdrup and Svensson 2002, 2004; Sverdrup

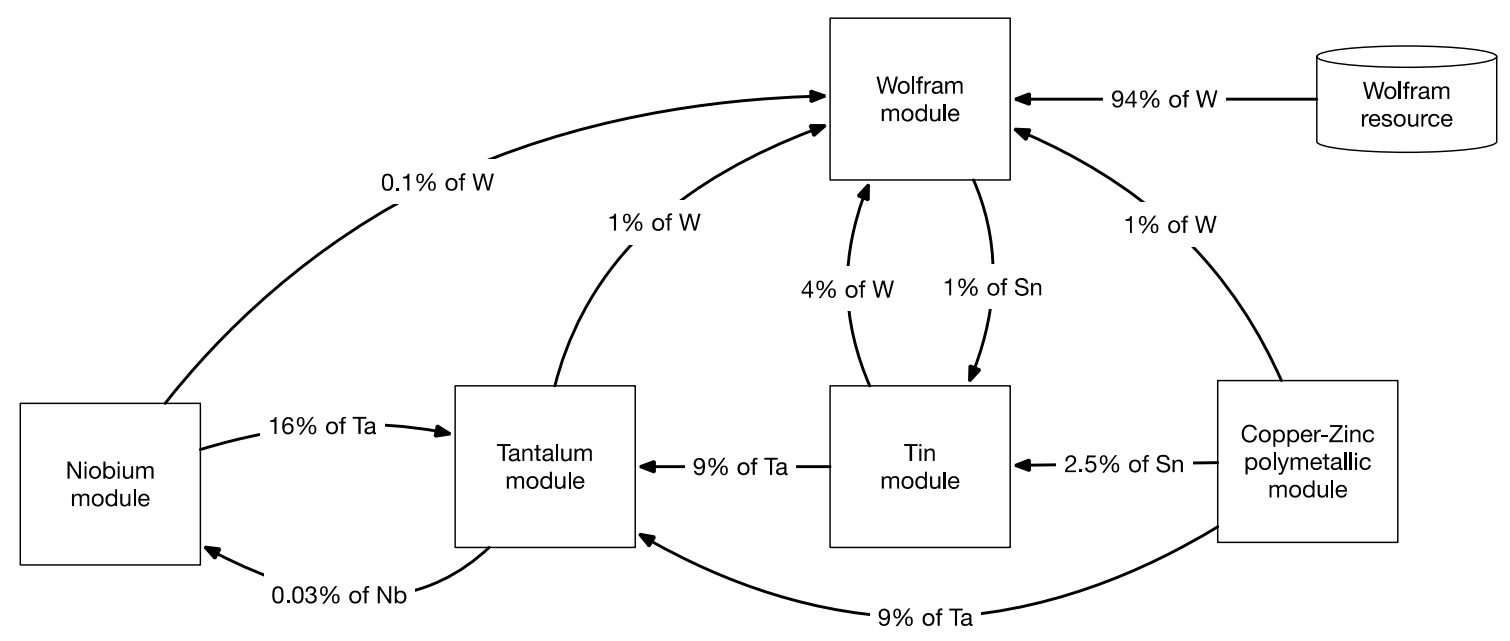

Fig. 4 A flow diagram for wolfram inside the WORLD6 model. The wolfram submodel combines the submodules for tantalum, niobium, wolfram and copper-zinc-lead and tin 


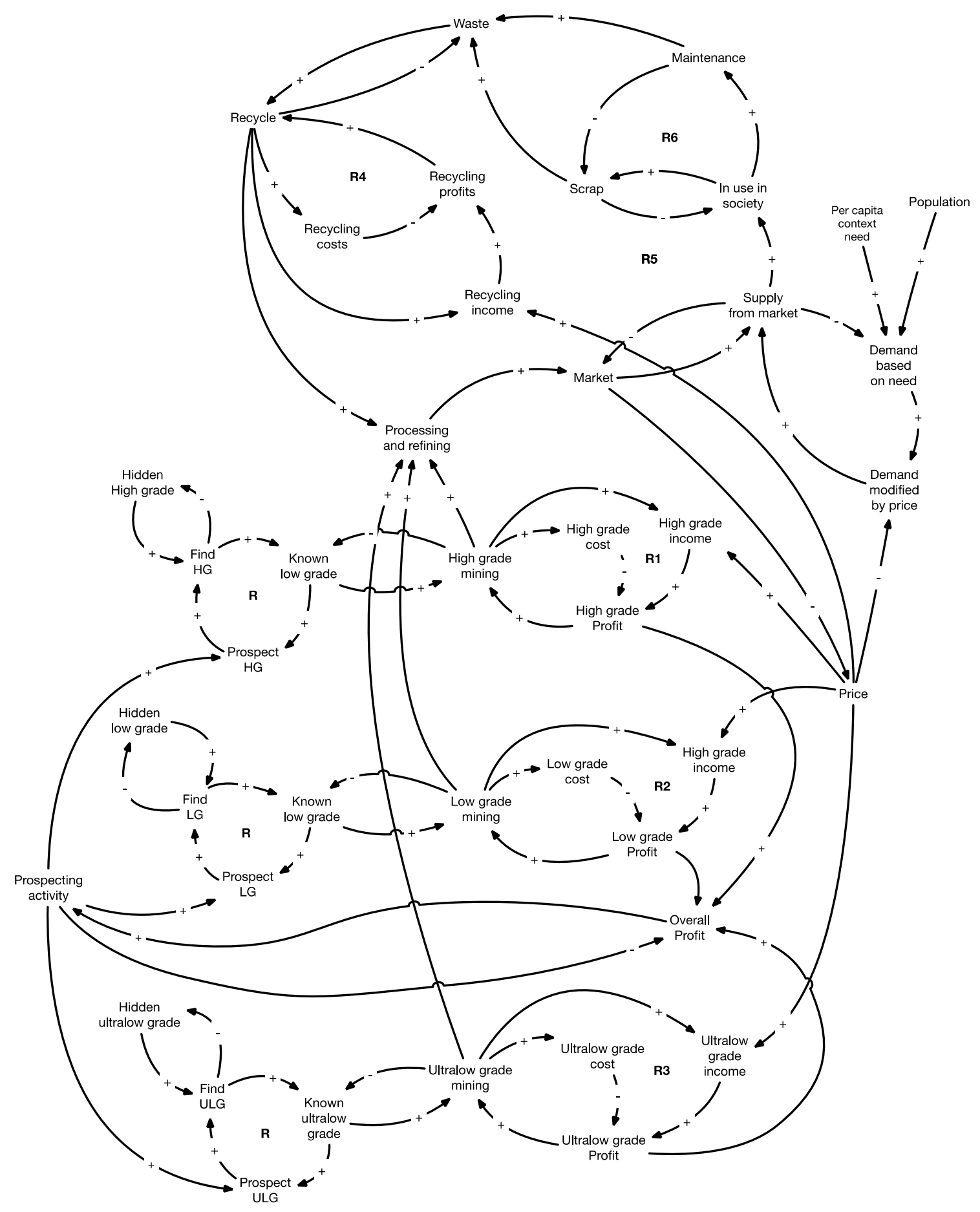

Fig. 5 Generic causal loop diagram for the market module in the WORLD6 model

et al. 2011, 2014a, b, 2015a, b, 2017). The causal loop diagrams are based on system analyses and they can be used to propose policy interventions. These diagrams are the map for the numerical model and they define the model. The model presented here was first used to reconstruct the past (1900-2015) to assess performance and robustness of the model. When the performance was satisfactory, then the model was used to simulate a possible future (2015-2400). These tools and methods have been employed earlier for assessments made for Rare Earths (Kifle et al. 2012), natural resources in general (Sverdrup et al. 2012b, 2013, 2015b; Sverdrup and Ragnarsdottir 2014a, b), copper 


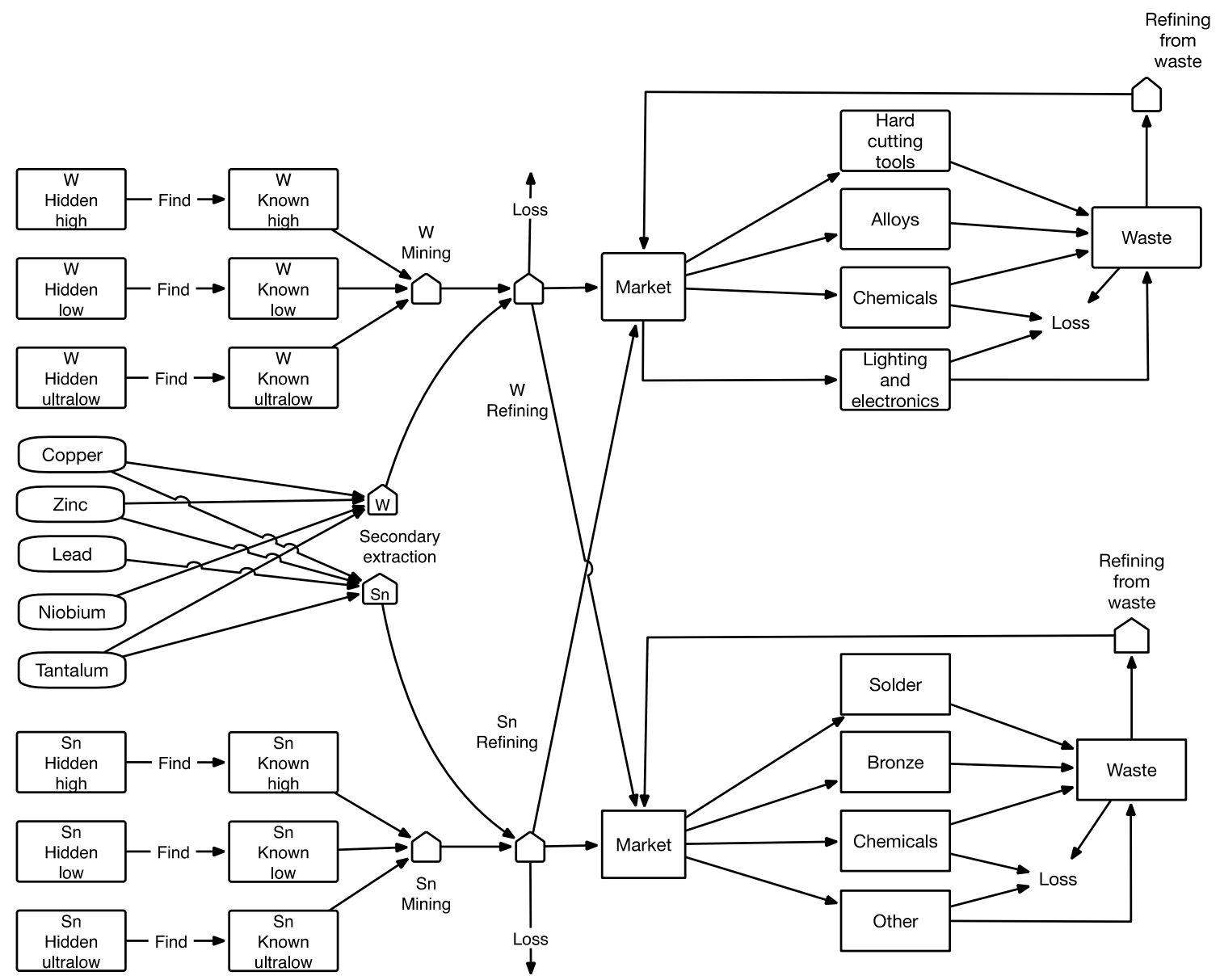

Fig. 6 Flow chart for the whole wolfram submodel, showing how wolfram production and tin production are cross-linked

(Sverdrup et al. 2014a), silver (Sverdrup et al. 2014b), aluminium (Sverdrup et al. 2015a), gold (Sverdrup et al. 2012a), platinum group metals (Sverdrup and Ragnarsdottir 2016a), lithium (Sverdrup and Ragnarsdottir 2016b), cobalt (Sverdrup et al. 2017) and further papers in preparation for iron, stainless steel, nickel, manganese, chromium, lead, zinc, indium, molybdenum, rhenium, niobium, tantalum, titanium, zirconium and hafnium.

\section{Resource Estimates}

The reserves estimates are based on classical geological estimates and the allocation of extractable amounts according to ore quality, stratified after extraction costs (Tilton 2009, 2012; Tilton and Lagos 2007; Neumeyer 2000; Rosenau-Tornow et al. 2009; Safirova 2013; USEPA 1994; USGS 2009, 2015; US Department of the Interior and Bureau of Mines and Geological Survey 1980). A number of literature sources were consulted, and the quantitative information was synthesized into a best possible estimate, here summarized in a number of tables. The target structure for the data is shown in Table 5. The different ways of estimating the ultimately recoverable amount of wolfram converge on 26-28 million ton of wolfram.

\section{Key Feedbacks and Coefficient Parameterization}

An important part of the modelling is to create causal structures. The causal structures often create feedback loops that are instrumental in creating the system dynamics. For these causal structures, we attempt to find independent parameterizations in such a way that the relationships should approach generic validity. This implies intensive work with literature synthesized, experimental data or empirical studies where the causal relationship can be isolated sufficiently well to capture a robust parameterization. Here we partially explain these when space allows, or sometimes refer to reports or other publications where this has been explained in detail. 


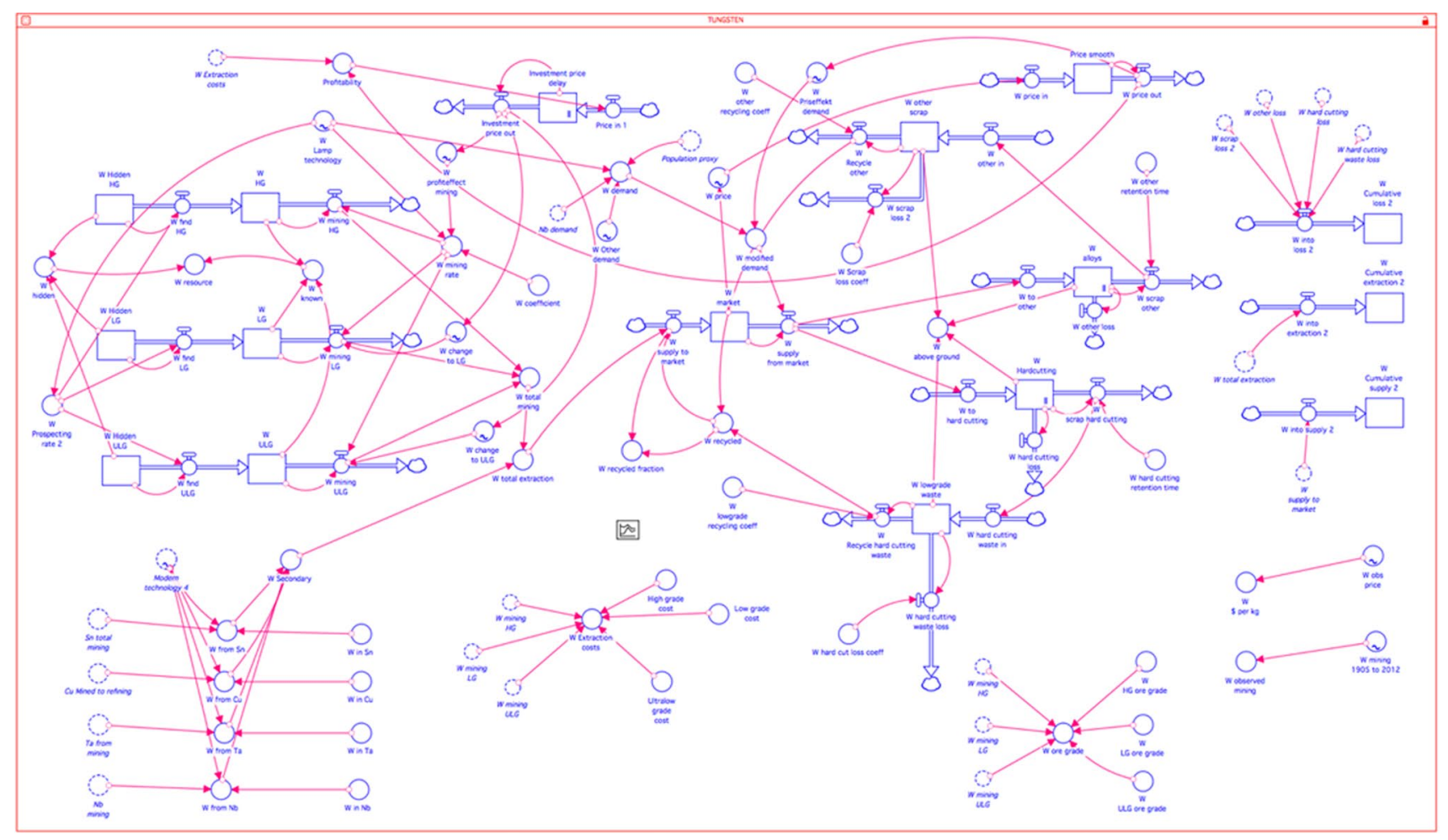

Fig. 7 Wolfram submodule in the WORLD6 model taken from the STELLA software. The module follows the logic of the causal loop diagram in Fig. 5 and the flow chart in Fig. 6

\section{Defining Scarcity}

Before we proceed further, we need to define what we imply with the term scarcity. We define scarcity as being of two types:

\section{Soft scarcity}

a. Initial demand is decreased because of higher prices when demand outmatches supply.

i. Reduced demand and reduced consumption are the result of price increases. Sometimes, a reduction in total consumption may be the result or substitution or simplification of provision.

2. Hard scarcity

a. Economic scarcity: The price goes high because of supply shortage and society runs out of money to buy.

i. Financial crisis may be the result, potentially inducing a recession.

b. Material scarcity: The material is physically unavailable regardless of price. i. Failure of a provision is the result, at risk for disruptions of economic stability. Stagnation or economic contraction may be the long-term result.

Normally, society can deal with soft scarcity without larger disturbances. It also implies that there is no shortage for those that are willing to pay what it costs. It often leads to innovations and/or substitution whenever that is possible. Hard scarcity is worse and may for certain materials or situations stimulate social unrest or stresses in society. Sometimes, a hard scarcity may lead to the loss of a certain technical capability. At the end of this paper, the supply situation is addressed with respect to these definitions.

\section{Resource Estimates}

New estimates of the extractable resource were made by the authors, independently of earlier attempts. Earlier data were also considered in the synthesis towards the final result. To put this together, a number of literature sources were consulted. We used extraction information and reserves and resources estimates from Andrews (1955), Chicharro et al. (2014), Crowson (2011), Dalnedra Vostok (2016), Heinberg (2001), Hughes (1990), International Business Publications (2013), Kesler and Wilkinson (2013a, b), Nassar et al. (2012), Ludington 
Table 2 Overview of remaining reserve in 2012 estimates

\begin{tabular}{|c|c|c|c|c|c|c|c|c|}
\hline \multirow[t]{2}{*}{ Metal } & \multirow{2}{*}{$\begin{array}{l}\text { Production } \\
2015 \text { ton/year }\end{array}$} & \multicolumn{4}{|c|}{ Million ton metal contained } & \multicolumn{3}{|l|}{$\%$ weight content } \\
\hline & & $\begin{array}{l}\text { USGS reserve } \\
\text { estimate }\end{array}$ & $\begin{array}{l}\text { USGS resource } \\
\text { estimate }\end{array}$ & $\begin{array}{l}\text { URR range at pre- } \\
\text { sent, our estimate }\end{array}$ & $\begin{array}{l}\text { Dug up } \\
\text { before } 2010\end{array}$ & $\begin{array}{l}\text { Typical workable } \\
\text { ore grades }\end{array}$ & Grade & $\begin{array}{l}\text { Lower } \\
\text { cut-off in } \\
\text { ore }\end{array}$ \\
\hline Wolfram & 88,000 & 9 & - & $16-30$ & 2.7 & $0.1-1.5$ & 0.4 & 0.10 \\
\hline Niobium & 63,000 & 4.3 & 5.4 & $16-25$ & 1.5 & $0.1-4$ & 0.4 & 0.01 \\
\hline Tantalum & 1400 & 0.150 & 0.26 & $0.32-0.4$ & 0.11 & $0.01-0.4$ & 0.03 & 0.01 \\
\hline Tin & 330,000 & 5 & 50 & 60.3 & 23.0 & $0.02-1$ & 0.05 & 0.01 \\
\hline
\end{tabular}

All amounts in metric ton. New data on resources from industrial unpublished sources and the British Geological Survey 2011

Table 3 Overview of recoverable resources, including all occurrences known or anticipated

\begin{tabular}{llllll}
\hline Metal & $\begin{array}{l}\text { Mother metal URR } \\
\text { (million ton) }\end{array}$ & $\begin{array}{l}\text { Wolfram in mother } \\
\text { metal (fraction) }\end{array}$ & $\begin{array}{l}\text { Wolfram flow (ton/ } \\
\text { year) }\end{array}$ & $\begin{array}{l}\text { Mother metal production in } \\
\text { 2012 (ton/year) }\end{array}$ & $\begin{array}{l}\text { Secondary wolf- } \\
\text { ram URR (million } \\
\text { ton) }\end{array}$ \\
\hline Wolfram & 22 & - & - & 88,000 & - \\
Niobium & 55 & 0.00400 & 300 & 65,000 & 0.220 \\
Tantalum & 0.6 & 0.00300 & - & 1200 & 0.002 \\
Tin & 60 & 0.00800 & 1800 & 300,000 & 0.480 \\
Copper & 4015 & 0.00004 & 610 & $17,000,000$ & 0.160 \\
Zinc & 2750 & - & 240 & $12,000,000$ & - \\
Lead & 3050 & - & - & $4,000,000$ & - \\
Polymetallic & - & - & - & - & - \\
Sum & - & - & - & & \\
\hline
\end{tabular}

All amounts in metric ton of metal

and Plumlee (2009), Lifton (2006), Lehmann et al. (2014), Kravchenko and Pokrovsky (1995), Leal-Ayala et al. (2015), Lele and Bhardwaj (2014), Mudd and Jowitt (2014), Mudd (2009), Nassar et al. (2012), Nickless et al. (2014), Nuss and Eckelmann (2014), Polyak (2011), Sverdrup et al. (2013), Schubert and Lassner (2010), Seddon (2013), Shedd (2003), Shiyu (1991), Sverdrup and Ragnarsdottir (2013, 2014a, b), Tilton and Lagos (2007), UNEP (2011a, b, c, 2013a, b, c), Visser (2002), Vulcan (2013), Walser (2002), Woodcock and Hamilton (1993), USGS $(2009,2015)$. There are a number of sources available for reserves, most of which have been summarized by the United States Geological Survey in their yearbooks (USGS 2015, it is freely available on the internet).

Tables 2, 3 and 4 show an overview of remaining wolfram reserves and wolfram resources in 2012 estimates. New data on resources were also taken from industrial unpublished sources and from the British Geological Survey 2011. Table 5 shows input data to the model based in reserves and resources in 1900 and estimated reserves and resources in 2011 for wolfram and tin. The average ore grade for the high grade was set at $5 \%$, for low grade at $1 \%$, for ultralow grade at $0.2 \%$ and for trace grade at $0.02 \%$.
Table 4 Overview of estimates of recoverable resources for wolfram and tin, including all occurrences known or anticipated

\begin{tabular}{lrl}
\hline Metal & Wolfram (ton) & Tin (ton) \\
\hline Primary deposits & $21,165,000$ & $20,250,000$ \\
Secondary amount & $2,000,000$ & $40,100,000$ \\
Dug up 1900-2015 & $3,300,000$ & $13,000,000$ \\
Total URR in 1900 & $26,165,000$ & $74,350,000$ \\
Dug up before 1900 & 100,000 & $10,000,000$ \\
Total URR & $26,565,000$ & $87,350,000$ \\
\hline
\end{tabular}

All amounts in metric ton of metal

Tin is also included with the input resource data in Table 5 needed to run the tin submodule to supply wolfram.

\section{Model Description}

The flow pathways, causal chains and feedbacks loops in the global tantalum-niobium-wolfram-tin system were mapped using system analysis, and the resulting coupled differential equations were transferred to computer codes for numerical solutions, using the STELLA ${ }^{\circledR}$ environment. 
Table 5 Input data to the model

\begin{tabular}{|c|c|c|c|c|c|c|c|}
\hline \multirow[t]{2}{*}{ Ore grade } & \multicolumn{4}{|c|}{ Wolfram 2011 (million ton) } & \multicolumn{3}{|c|}{ Wolfram 1900 (million ton) } \\
\hline & Known & Hidden & Dug up & Sum & Known & Hidden & Sum \\
\hline High & 1.1 & 0.9 & 1 & 3.0 & 0.6 & 5.4 & 6 \\
\hline Low & 3.0 & 5.0 & 1 & 9.0 & 1.0 & 8.0 & 9 \\
\hline Ultralow & 2.0 & 9.0 & 0 & 11.0 & 0.0 & 12.0 & 12 \\
\hline Sum & 6.1 & 14.9 & 2 & 23.0 & 1.6 & 25.4 & 27 \\
\hline \multirow[t]{2}{*}{ Ore grade } & \multicolumn{4}{|c|}{ Tin 2100 (million ton) } & \multicolumn{3}{|c|}{ Tin 1900 (million ton) } \\
\hline & Known & Hidden & Dug up & Sum & Known & Hidden & Sum \\
\hline High & 1 & 5 & 7 & 12 & 7 & 4 & 12 \\
\hline Low & 15 & 15 & 3 & 33 & 3 & 30 & 33 \\
\hline Ultralow & 10 & 20 & 0 & 30 & 0 & 30 & 30 \\
\hline Sum & 26 & 45 & 10 & 75 & 10 & 64 & 75 \\
\hline
\end{tabular}

Reserves and resources in 1900 and estimated reserves and resources in 2011 for wolfram and tin

Figure 5 shows the causal loop diagram for the market module in the WORLD6 model. There it can be seen how the mining is profit driven, including both costs and income from metal sales. The model was developed to estimate supply, extractable amounts, price and stocks, and flow in society in the time interval 1900-2400. Figure 6 shows the basic flow chart used for the wolfram submodel. The wolfram submodel has the following stocks used to define the coupled differential equations defined by mass balance:

1. Wolfram

a. Mineable stocks

i. Known

1. high grade

2. low grade

3. ultralow grade

\section{ii. Hidden}

1. high grade

2. low grade

3. ultralow grade

b. In society, we distinguish three wolfram stocks
i. Trade market
ii. Stock-in-use in society
iii. Waste

c. Dependent five stocks of wolfram in other metals
i. Stocks in copper
ii. Stocks in zinc
iii. Stocks in tantalum

iv. Stocks in niobium

2. Tin

a. Mineable stocks

i. Known

1. high grade

2. low grade

3. ultralow grade ore

\section{ii. Hidden}

1. high grade

2. low grade

3. ultralow grade ore

b. In society, we distinguish three tin stocks
i. Trade market
ii. Stock-in-use use
iii. Waste

c. Dependent five stocks of tin in other metals
i. Stocks in copper ore
ii. Stocks in zinc ore
iii. Stocks in lead ore
iv. Stocks in wolfram ore
v. Stocks in tantalum ore

The model has 9 dependent stocks for secondary extraction and 18 independent stocks, solved from the differential equations defined by mass balance. All stocks have defined inputs and outputs, conforming to the equation:

Inputs + produced $=$ accumulated + outputs. 
This can be rearranged to:

$\frac{\mathrm{d} m}{\mathrm{dt}}=$ inputs + produced - outputs.

The inputs represent returns from recycling and are produced from primary and secondary extraction. Accumulated represents what is accumulated in society either as stocks-inuse or as scrap. Outputs represent what is lost or recycled. Note that recycled is present on both sides and thus increase the flow through society. To meet a certain supply to society, the larger the recycling, the smaller the primary extraction must be to meet the demand. Dependent stocks are cumulative amounts of mined, amounts of rock waste, losses, smelter slag and ore found by prospecting. The mining activity is profit driven, and the profit is affected by the mining cost and the market price (see Fig. 7 for the exact model used). A lower ore grade implies that more rock must be moved to mine the metals. In the model, mining and recycling are profit driven as shown in Fig. 5. Sales of extracted metal together with the price, given the income, the extraction and prospecting give the costs, the profit being the difference. In the model, shift to a lower ore grade only occurs when the market price exceeds the extraction cost in such a way that the profit stays positive. When the profit is lower or goes negative, the mining rate is slowed down, leading to less material in the market, driving the price up. In practice, we have several sources of metal in the society: the high, low and ultralow ore grades and the stocks of metal in society that can be recycled. For wolfram, mining occurs from the three different ore grades mentioned above. The lower the ore grade, the higher the extraction cost will be. Wolfram is obtained by secondary extraction from tin ores, as well as recycling of a fast stock of chemicals and catalysts and a slow stock of metallic alloys (Fig. 4). The mining rate follows a rate equation depending on the mineable reserve, the profitability of the operation and the available mining technology:

$r_{\text {mining }}=\mathrm{k} \times m_{K} \times f$ (profit) $\times g($ technology $)$,

where $r_{\text {mining }}$ is the rate of mining, $\mathrm{k}$ is the rate coefficient and $m_{K}$ is the mass of the ore body known and available for extraction. The rate coefficient is modified with ore extraction cost and ore grade. In the model, a delay in mining rate change is considered using a forward rolling 2-year average of the market price. $g$ (technology) is a technology factor accounting for the invention of technologies used in efficient mining, refining and extraction. $f$ (profit) is a feedback function of market price, increasing mining at higher price and lowering it at lower metal prices.

Profit $=$ Income from sales - mining costs

where the costs are defined as

Total costs $=$ Mining costs + refining costs

$$
+ \text { prospecting costs }+ \text { capital costs. }
$$

In this equation, mining, refining and prospecting costs all include both variable operation costs and capital costs for infrastructures and equipment, as well as a $10 \%$ profit margin. The income is defined as

Income from sales $=$ Amount sold $\times$ market price - sales costs .

The size of the extractable ore body is determined by the rate of extractions $\left(r_{\text {mining }}\right)$ and the rate of prospecting $\left(r_{\text {discovery }}\right)$ :

$\frac{\mathrm{d} m_{K}}{\mathrm{dt}}=-r_{\text {mining }}+r_{\text {discovery }}$.

The discovery is a function of how much prospecting is done and how much there is left to find. The amount of hidden reserve $\left(m_{H}\right)$ decreases with the rate of discovery. The rate of discovery is dependent on the amount of metal hidden $\left(m_{H}\right)$ and the prospecting coefficient $k_{\text {prospecting. }}$ The prospecting coefficient depends on the amount of effort spent and the technical method used for prospecting. We use the following equation for calculating the rate of discovery:

$r_{\text {discovery }}=\frac{\mathrm{d} m_{H}}{\mathrm{dt}}=-k_{\text {prospecting }} \times m_{H} \times g($ technology $)$.

The amount hidden in the resource is represented by $m_{H}$. The basic driving mechanism of basic mining comes from profits and availability of a mineable resource used in the model. The price is set relative to how much metal there is available in the market. $g$ (technology) is a function accounting for improved prospecting techniques coming with modern society and technological development. The extraction rates of wolfram $\left(R_{W}\right)$ in the model are calculated as follows:

$R W=r_{W}+r_{j} \times \sum_{i=1}^{i=n} X_{i(j)}$,

where $X_{j(i)}$ is the fraction of metal $j$ in mother metal $i$ and $r_{j}$ is the mining rate of metal $j$, considering $n$ different mother metals. The most important mother metal for secondary wolfram is tin, copper and polymetallic ores (Table 3). It can be seen from the causal loop diagram that the mining operation is driven by operations profit as shown in Fig. 5. This profit is driven by metal price and the amount extracted, but balanced by the cost of operation. The mining rate is related to the state of the technology, and it has two alternatives: (1) either the technology and the financial capacity determine the mining rate and the ore body is always sufficient to supply anything attempted to be extracted, or (2) the mining rate is unrelated to the technical and financial capacity and limited by the access to the ore body. 
There are many different definitions of recycling available (Graedel and Allenby 2003, UNEP 2011b, 2013a). For the purpose of clarity, the recycling fraction displayed in results is calculated as follows in this study:

Recycling fraction $=\frac{\text { Flow of recycled metal }}{\text { Extraction of recycled metal }}$.

The cost of the mining and extraction operation is mainly determined by two important factors besides cost of investments, i.e. the energy price and the ore grade. The price is determined by two factors, that it must stay above the production costs and by the amount in the market. A number of feedback response curves are employed in the model and are shown conceptually in Fig. 5, and with response functions in Fig. 8. The wolfram demand was estimated using the demand from specialty steel, lighting technology, an empirical function and a general proportionality to population. The equation used to estimate the wolfram demand is (in million ton of wolfram per year)

$W_{\text {demand }}=0.07 \times N b_{\text {demand }}+0.01 \times f(L T)+W_{\text {Other }}+$ Global $\times 0.005$,

where $f(\mathrm{LT})$ is a technology development scaling function and wolfram's use in glow filaments. The causal loop diagram maps the causal relationships in the system as they are depicted in the model as shown in Fig. 5. This has been applied in the wolfram submodule. The Rs in the diagram represent the reinforcing loops. These are the loops that keep the system running.

Factor $\mathrm{X}$ is used to estimate the resource use efficiency of a material. Factor $\mathrm{X}$ varies over time and thus an alternative measure would be the instant Factor $\mathrm{X}$ :

Factor $\mathrm{X}=\frac{\text { Market supply rate }}{\text { Extraction rate }}$.

This measures the Factor $\mathrm{X}$ for the moment and changes with time as the extraction rate and the recycling efficiency vary with time. Figure 7 shows the STELLA ${ }^{\circledR}$ diagram for wolfram submodule inside the WORLD6 model. Figure 8 shows some diagrams with response functions from the model. In the upper row are shown from left to right the market amount-to-price relationship, the demand per capita, the intensity of wolfram use in lighting technology, and in the middle row the shift price from high-grade ore to low-grade ore. In the bottom row, the price modification of demand and the profit drive on mining are shown. The WORLD6 model is based on mass balance expressed as differential equations and solved numerically with a

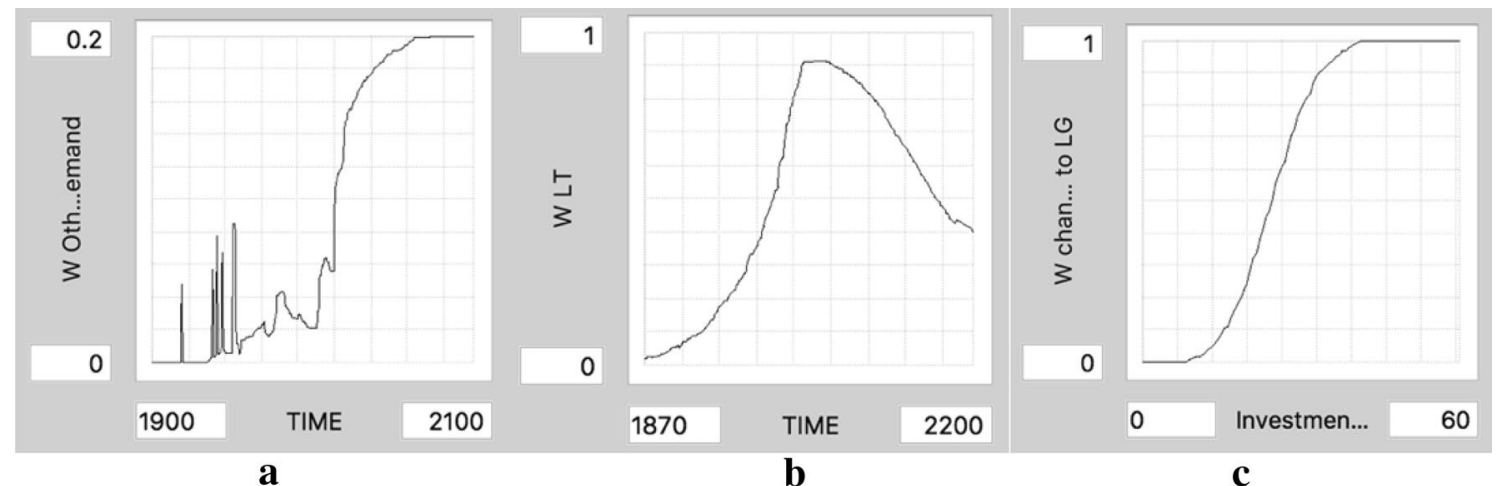

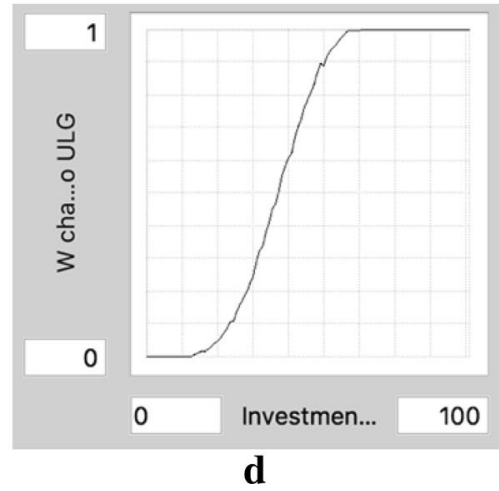

Fig. 8 Parameterization of the wolfram module. a The wolfram demand, b the technology scaling factor for wolfram use in lighting technologies, $\mathbf{c}$ the change price from high grade to low grade, $\mathbf{d}$ the change price from low grade to ultralow grade, $\mathbf{e}$ the price effect on demand and $\mathbf{f}$ the profit feedback function 
four-step Runge-Kutta method, using a 0.05-year timestep. It is far beyond the scope of this model to explain the full WORLD6 model here. It can be seen from the causal loop diagram that the mining operation is driven by operating profit as shown in Fig. 5. This profit is driven by metal price and the amount extracted but balanced by the cost of operations. The relation to the state of the extraction technology has two alternatives: (1) either the technology or the financial capacity determines the mining rate and the ore body is always sufficient to supply anything attempted to be extracted, or (2) the mining rate is unrelated to the technical and financial capacity and limited by the access to the ore body. We have considered in the model both factors being active. There is a technology scaling function, and the extraction is limited by the progress through the different ore qualities. The cost of the mining and extraction operation is mainly determined by two important factors besides the cost of investments: the energy price and the ore grade. The price is determined by two factors, that it must stay above the production costs and by the amount in the market. A number of feedback response curves are employed in the model. The price curves relate the tradable amount in the market to the market price. Figure 9 brings together such data for wolfram. These curves were first developed from data on copper, silver, gold and platinum trading by the first author's personal notes and experiences from trading floors in London and New York.

\section{Input Data and Parameters}

The parameterization is consistent with what we have done earlier for metals. The market amount-to-price relationship turns out to be very similar among many metals. The same is the case for the price effect on demand and the profit push on mining. There are fundamental market settings (Sverdrup et al. 2012b, 2013, 2015b, 2014a, b, 2017, Sverdrup 2016). Before it is possible to use the model to simulate results, it needs to have its input parameters set properly, and the resource database set up. The available extractable resources are stratified as shown in Table 5. The extractable amounts were set at the beginning of the simulation in 1900, stratified with respect to ore metal content. Figure 10 shows the overview of the WORLD6 submodules.

\section{Sensitivity}

The model reproduces the observed mining rate and the historic market price and reproduces the ore grade well, even if there are little data available. This indicates that the main causative elements have been incorporated in the model and suggests that further complication of the model may not necessarily make it better. The model is quite sensitive to the demand function used. The demand was estimated

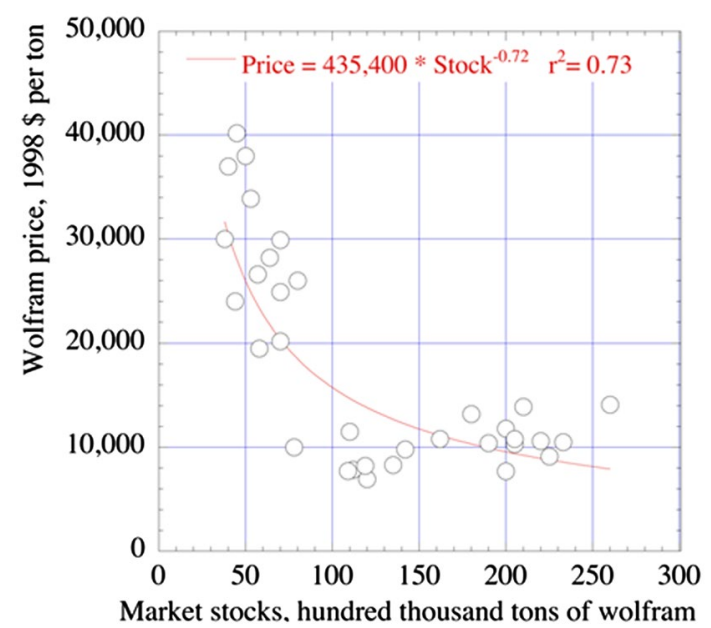

Fig. 9 The recorded market amounts related to the observed market price. The relationship was used in the model price simulation

in the model as a curve depending on metal uses in other parts of the model and a component dependent on population only, but modified with inputs on connected demands from elsewhere in the WORLD6 model. A proper sensitivity analysis is planned for the simulation of wolfram at a later date, and it is outside the scope of this paper.

\section{Results}

The WORLD6 model was run for the period of 1900-2400, in order to investigate all major changes. The results for wolfram are shown in Figs. 11, 12, 13, 14, 15 and 16. The runs represent a business-as-usual scenario. Further scenarios are deferred to later studies. Note that the resource estimates developed in Tables 1, 2, 3 and 4 are important results of this work, enabling the creation of the input data presented in Table 5, used to start the model. The market price curve is presented in Fig. 9. It shows the price curve determined from wolfram market data. The price expressed in 1998 inflation-adjusted dollars was plotted against market amounts, including the US strategic stockpile, the London Metal Exchange stocks and the tradeable stocks held at private corporations, traders and producers, to develop the price diagram in Fig. 9. The correlation between the market amounts and price is $r^{2}=0.72$. The London Metal Market stocks are in the range of 20,000-50,000 ton.

Wolfram production, supply, recycling and market price were modelled for the time period of 1900-2400. Figure 11 shows the mining rate for wolfram and how the different ore grades contribute. It can also be seen how well the historical mining rate is reproduced. Figure 12a shows the total production, the secondary extraction and the mining of wolfram. Figure $12 b$ shows the 


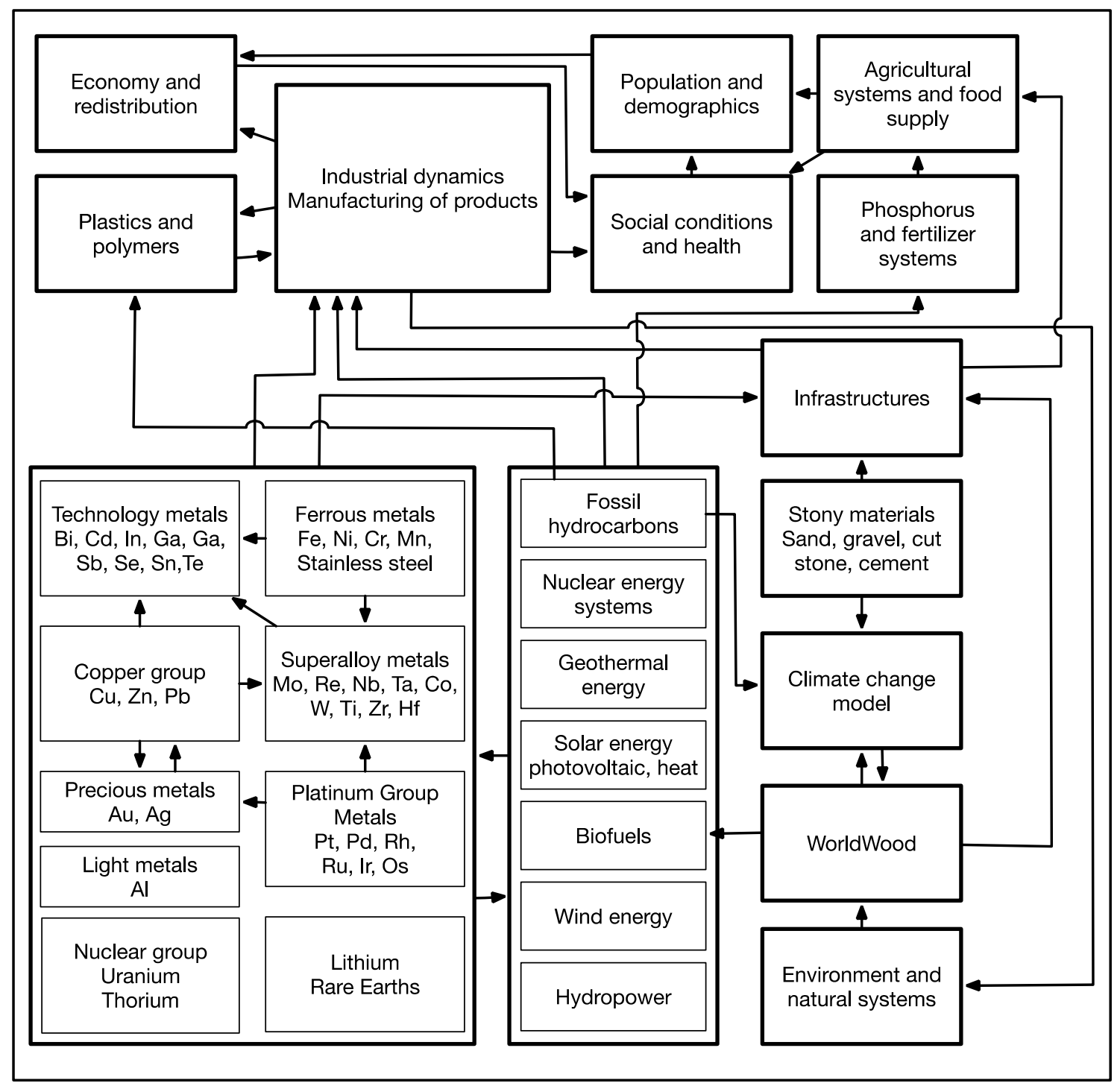

Fig. 10 Overview of the WORLD6, version 6.166, as of 1st July 2017

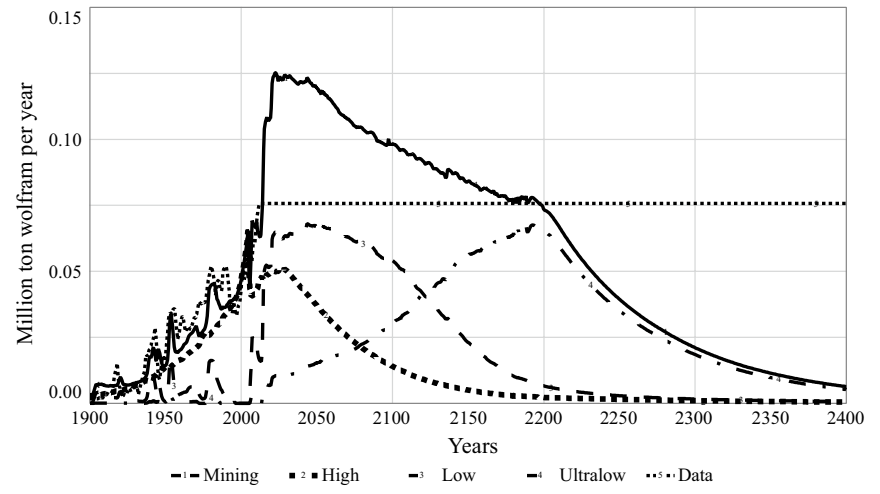

a

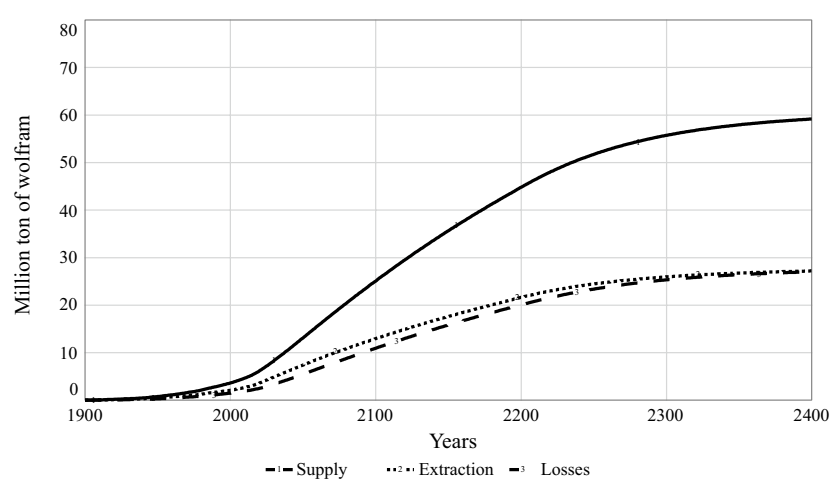

b

Fig. 11 Model outputs from WORLD6 for wolfram and how the different ore grades (high, low, ultralow) contribute to the estimated mining. This has been compared to the observed mining rate (a). b Cumulative amounts of wolfram extracted, the losses and the total supply 


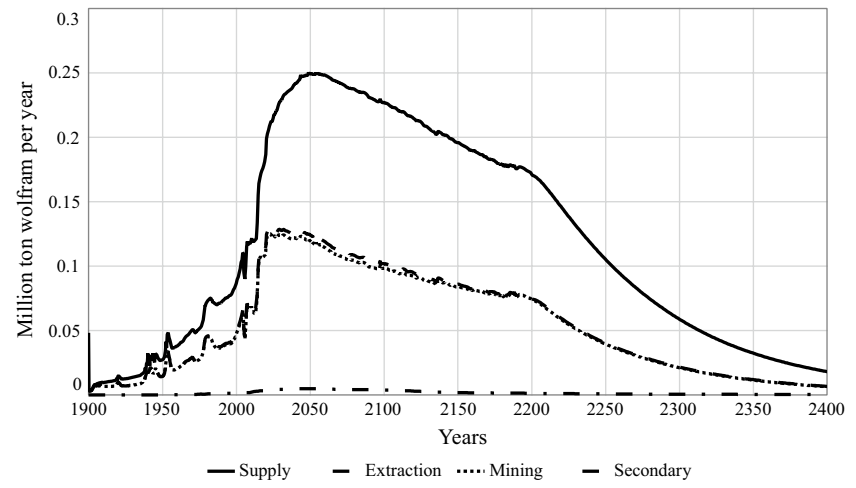

a

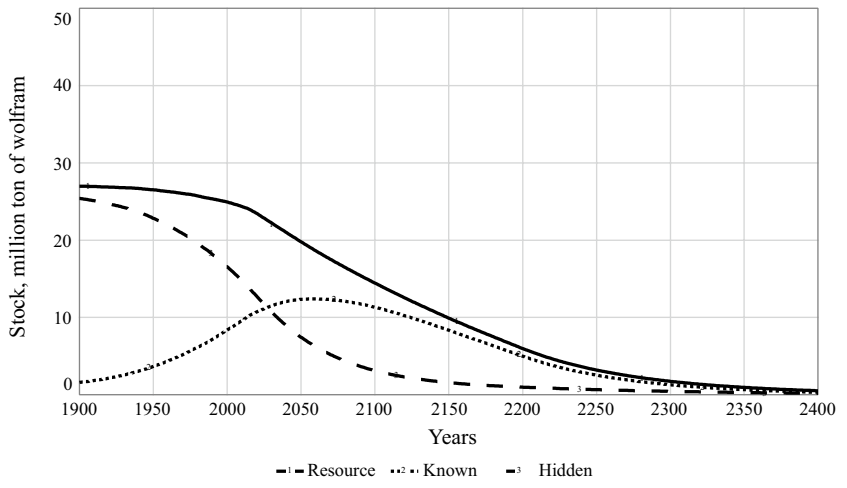

b

Fig. 12 Model outputs from WORLD6 for wolfram, showing total extraction, mining, secondary extraction and supply from the market to society (a). b The known reserves, the hidden resources and the total resource over time

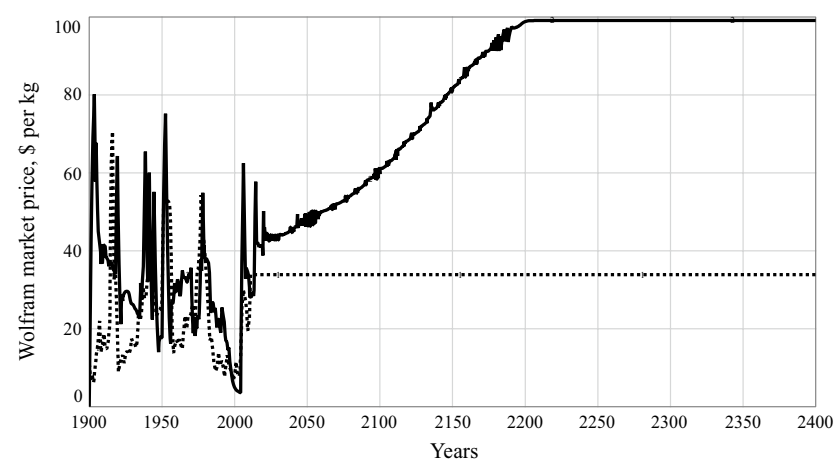

.... Observed $\quad=-$ Modelled price

$\mathbf{a}$

Fig. 13 Model outputs from WORLD6 for the simulated market price of wolfram (solid line) as compared to the observed market price (dotted line) and the modelled market price. The flat part of the

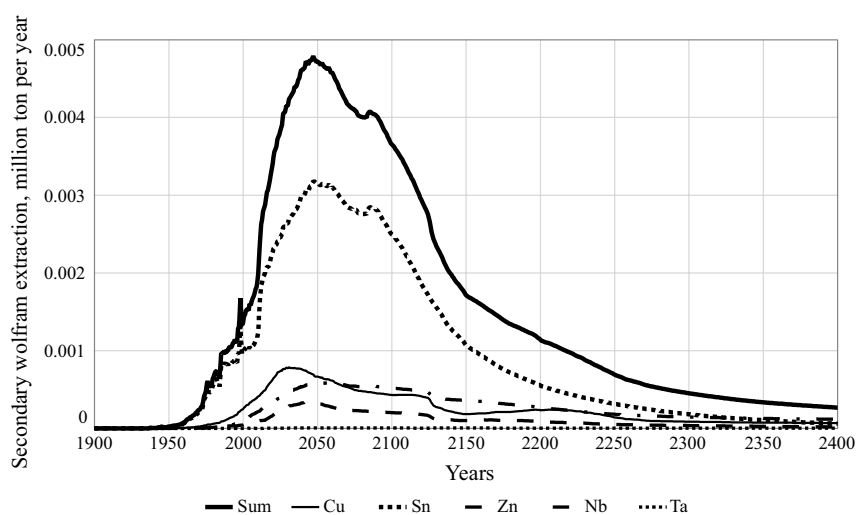

b

curve after 2015 can be ignored. b Origin of the secondary extraction from copper $(\mathrm{Cu})$, tin $(\mathrm{Sn})$, zinc $(\mathrm{Zn})$, niobium $(\mathrm{Nb})$ and tantalum (Ta). The thick line is to be secondary extraction (Sum)

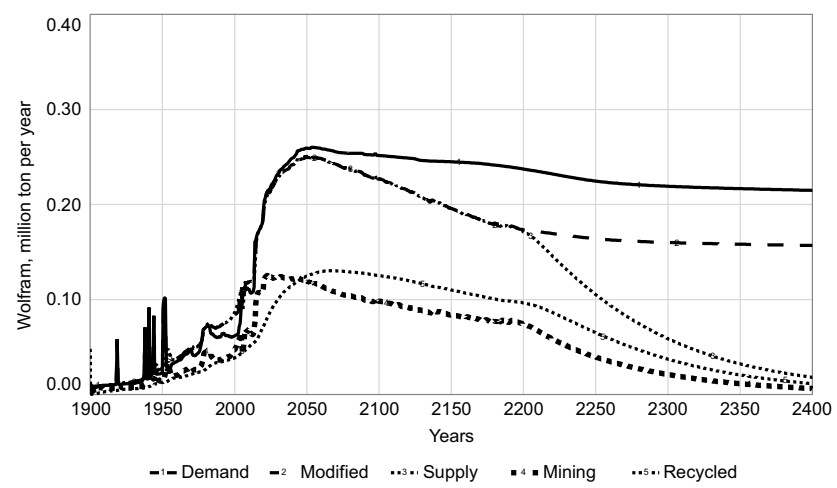

a

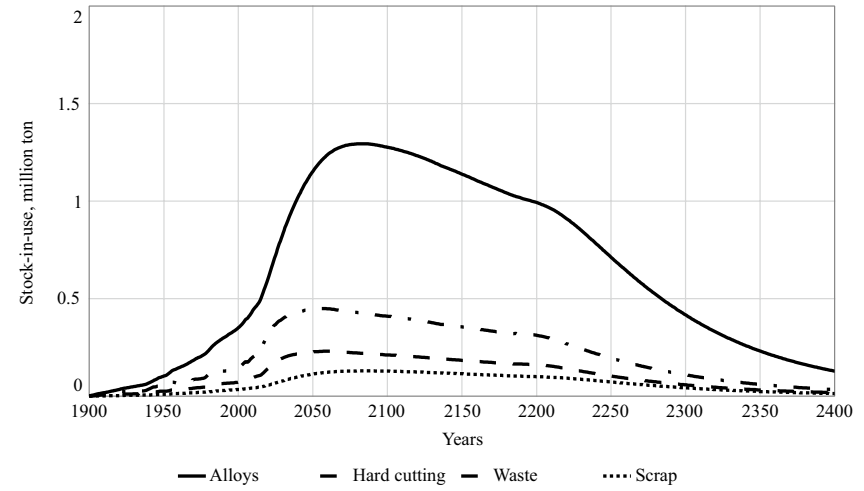

b

Fig. 14 Model outputs from WORLD6 for wolfram, demand, demand after modification by price, supply, mining and recycled annual amounts (a). Different stocks-in-use for different wolfram categories (b) 


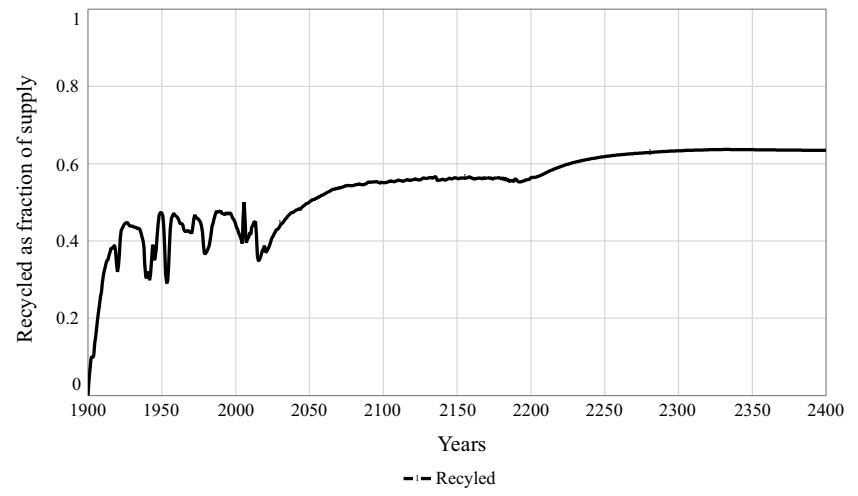

$\mathbf{a}$

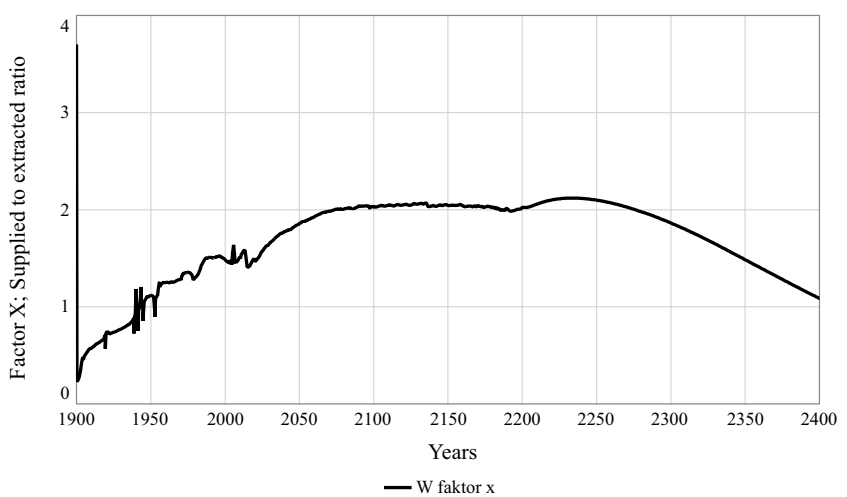

b

Fig. 15 The simulated wolfram recycling degree as a fraction supply (a) and the Factor X for wolfram (b)

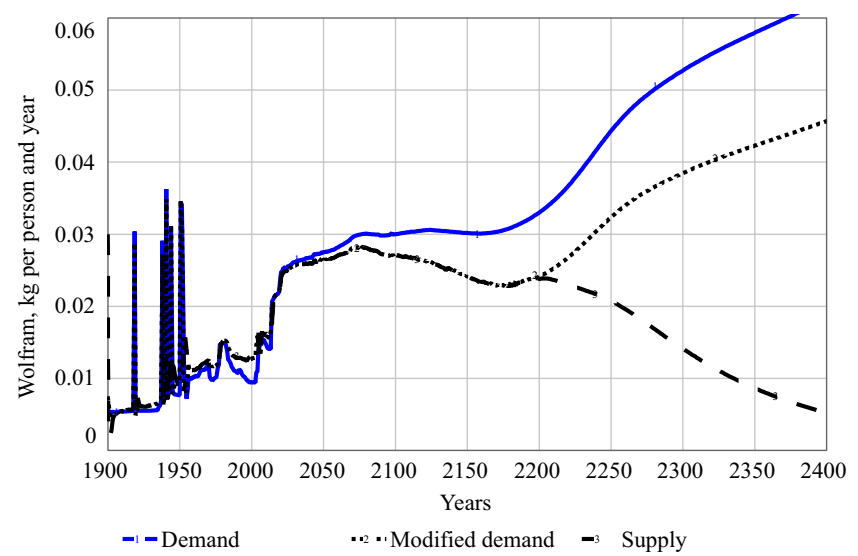

a

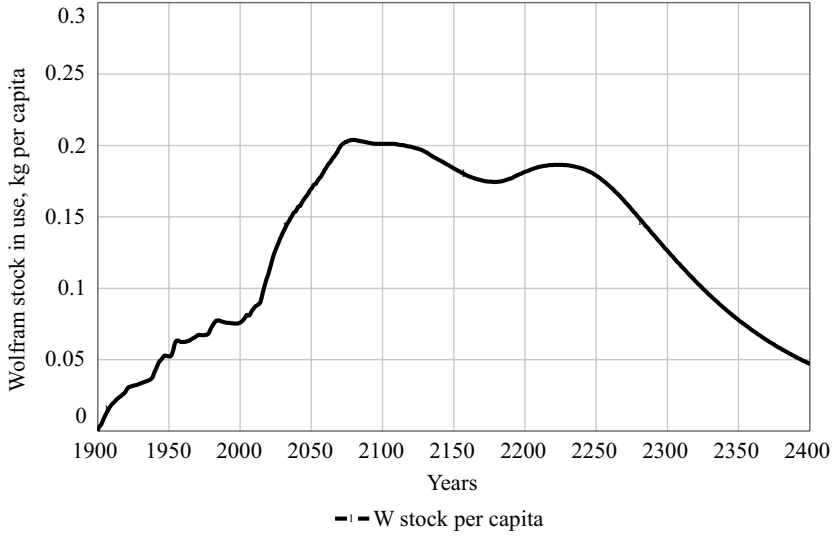

b

Fig. 16 Wolfram supply in kg per person and year (a), compared to the demand before any price adjustments. Wolfram stock-in-use per capita is an indicator for service provision per person (b)

development of the known, hidden and total resources over time. Figure 13a shows a comparison of the observed market price and the modelled market price. Figure $13 \mathrm{~b}$ shows the origin of the secondary extraction from copper $(\mathrm{Cu})$, zinc $(\mathrm{Zn})$, niobium $(\mathrm{Nb})$ and tantalum (Ta). Figure 14a shows the demand for wolfram, the demand after modification by the price, which closely overlaps on the actual supply, as compared to the mining rate and the recycling rate. Figure $14 \mathrm{~b}$ shows the stocksin-use as alloys, hard cutting tools, low-grade waste and metallic scrap. Wolfram does not seem to run into any serious scarcity based on the demand assumptions we are using. Figure 15a shows the simulated recycling degree and Factor $\mathrm{X}$ for wolfram (Fig. 15b). Wolfram recycling is at present $35-40 \%$ and is expected to rise to about $50 \%$, implying a Factor $X=2$. Factor $X$ is the ratio of supplied to net extracted.

\section{Discussion}

In the future, wolfram can be expected to have an increasing demand, as there are many advanced technologies where it gives a technical advantage. Two parameters are the most important for the assessment of scarcity: global average supply per capita per year and global average stock-in-use per capita. These two indicators are plotted to assess the nature of the potential future scarcity (Fig. 16).

- Supply per person per year is necessary to assess whether we can have growth, if we will get global stagnation or global contraction (Fig. 16a).

- Stock-in-use per person is necessary to assess whether we can increase global utility provision, if it will develop into global stagnation or global contraction (Fig. 16b). 
In this assessment, Fig. 16a is the key diagram for the scarcity assessment. Here we can relate demand, demand modified by price and the amount supplied by the system. When these curves are not overlapping, then there is some type of scarcity, either soft or hard. When demand and demand modified by price separate, we have soft scarcity. When demand modified by price and supply separate, we have hard scarcity. Soft scarcity occurs around 2030, and hard scarcity occurs after 2200 because of resource exhaustion.

It can be observed from Fig. 16b that the wolfram stock-in-use per capita is an indicator for service provision per person as calculated by the model. The stockin-use declines after 2070, first slowly, then fast (after 2220), and service provision is lost. There will be a significant wolfram scarcity problem after 2200 .

\section{Conclusions}

The model outputs suggest that there will be a soft scarcity around 2030 and hard scarcity after 2200 for wolfram. We conclude that we are able to model the observed pattern for mining, extraction, ore grades and market price, based on mass balance and market principles with good accuracy, and sufficient for policy development use. The complexity of the WORLD6 model allows for many cross-linking aspects to be considered which were not possible with earlier and cruder concepts.

The WORLD6 is based on a number of assumptions. These assumptions can be considered as a strong and a weak point. Many of the assumptions cannot be checked well until afterwards. But the model has proven to be able to reflect the past with good success, suggesting that the unverifiable assumptions cannot be too far off the mark. We assume, based on the success with reconstructing the past, that the runs for the future are a good estimate for what will come.

\begin{abstract}
Acknowledgements This study was conducted at the Icelandic System Dynamics Center (ISDC) at the University of Iceland. This study contributed to the SimRess project ("Models, potential and long-term scenarios for resource efficiency") funded by the German Federal Ministry for Environment and the German Environmental Protection Agency (FKZ 371293 102). Dr. Ullrich Lorenz is the project officer at the German Environmental Protection Agency (UBA).
\end{abstract}

\section{Compliance with Ethical Standards}

Conflict of interest The authors declare that there is no conflict of interest.

\section{References}

Andrews MG (1955) Tungsten, the story of an indispensable metal. The wolfram Institute, Washington DC

Asian Metal (2017) Tungsten: resource distribution and production. http://metalpedia.asianmetal.com/metal/tungsten/ resources\&production.shtml

Chicharro E, Martın-Crespo T, Gomez-Ortiz D et al (2014) Geology and gravity modeling of the Logrosan Sn-W ore deposits (Central Iberian Zone, Spain). Ore Geology Rev 65:297-304. doi:10.1016/j.oregeorev.2014.10.005

Crowson PCF (2011) Mineral reserves and future minerals availability. Mineral Econ 24:1-6

Daigo I, Matsuno Y, Adachi Y (2010) Substance flow analysis of chromium and nickel in the material flow of stainless steel in Japan. Resour Conserv Recycl 54:851-863

Dalnedra Vostok (2016) 20 июля 2012 года. Соболиное, месторождение. Источник: http://nedradv.ru/ajax/cards/cards. cfm?id_obj=a56a2a04b5f2a9dbee29af0a78087aff.nedradv.ru

Graedel TE, Allenby BR (2003) Industrial ecology, 2nd edn. Pearson Education Inc. AT \& T, NJ, 363 p

Haraldsson HV, Sverdrup HU (2004) Finding simplicity in complexity in biogeochemical modelling. In: Wainwright J, Mulligan M (eds) Environmental modelling: a practical approach. Wiley, Chichester, pp 211-223

Heinberg R (2001) Peak everything: waking up to the century of decline in earth's resources. Clairview, Forest Row, pp 270

Hughes FE (ed) (1990) Geology of the mineral deposits of Australia and Papua New Guinea, Monograph 14. Australasian Institute of Mining and Metallurgy, Melbourne

International Business Publications (2013) Ukraine: mineral, mining sector investment and business guide. Strategic informations and regulations, vol 1. International Business Publications, Washington DC, p 230. ISBN: 978-1-4330-5184-2

International Business Publications (2015) Russia and newly independent states (NIS) 2015: mining and mineral handbook. Russia mining industry: strategic information, regulations, contacts, vol 1. International Business Publications, Washington DC, $\mathrm{p}$ 312. ISBN: 978-1-329-09121-4

Kesler SE, Wilkinson BH (2013a) Earth's copper resources estimated from tectonic diffusion of porphyry copper deposits. Geology 41:255-258

Kesler SE, Wilkinson BH (2013b) Tectonic-diffusion estimates of global mineral resources: extending the method-granitic tin deposits. In: Jenkin GRT, Lusty PAJ, McDonald I, Smith MP, Boyce AJ, Wilkinson JJ (eds) Ore deposits in an evolving earth. Geological Society, London. doi:10.1144/SP393.6

Kifle D, Sverdrup H, Koca D, Wibetoe G (2012) A simple assessment of the global long term supply of the rare earth elements by using a system dynamics model. Environ Nat Resour Res 3:115. doi:10.5539/enrr.v3n1p77

Kravchenko SM, Pokrovsky BG (1995) The Tomtor alkaline-ultrabasic massif and related REE-Nb deposits, northern Siberia. Econ Geol 90:676-689

Leal-Ayala DR, Allwood JM, Petavratzi E, Brown TJ, Gunn G (2015) Mapping the global flow of tungsten to identify key material efficiency and supply security opportunities. Resour Conserv Recycl 103:19-28. doi:10.1016/j.resconrec.2015.07.003.

Lehmann B, Halder S, Munana JR, de la Paix Ngizimana J, Biryabarema $M(2014)$ The geochemical signature of rare-metal pegmatites in Central Africa: Magmatic rocks in the Gatumba tin-tantalum mining district, Rwanda. J Geochem Explor 144:528-538

Lele A, Bhardwaj P (2014) Strategic materials. A resource challenge for India. Pentagon Press, Institute for Defence Studies \& Analyses, New Delhi. pp 221. ISBN 978-81-8274-9 
Lifton J (2006) The trouble with tungsten. Hard Assets, Resource Investor website. http://www.resourceinvestor.com/2006/01/31/ trouble-tungsten

Ludington S, Plumlee GS (2009) Climax-type porphyry molybdenum deposits: US Geological Survey Open-File Report 2009-1215, $16 \mathrm{p}$

Mudd GM (2009) Nickel sul de versus laterite, the hard sustainability challenge remains. In: Proceedings 48th Annual Conference of Metallurgists, Canadian Metallurgical Society, Sudbury, August 2009

Mudd GM, Jowitt SM (2014) A detailed assessment of global nickel resource trends and endowments. Econ Geol 109:1813-1841

Nassar NT, Barr R, Browning M, Diao Z, Friedlander E, Harper EM, Henly C, Kavlak G, Kwatra S, Jun C, Warren S, Yang M-Y, Graedel TE (2012) Criticality of the geological copper family. Environ Sci Technol 46:1071-1078

Neumeyer E (2000) Scarce or abundant? The economics of resource availability. Econ Surv 14:307-315. doi:10.1111/1467-6419.00112

Nickless E, Bloodworth A, Meinert L, Giurco D, Mohr S, Littleboy A (2014) Resourcing future generations white paper: mineral resources and future supply. Int Union Geol Sci 44

Nuss P, Eckelmann MJ (2014) Life cycle assessment of metals: a scientific synthesis. PLoS One 9:e101298. doi:10.1371/journal. pone.0101298

Polyak DE (2011) USGS mineral commodity summary: Rhenium. US Geological Survey, Reston, VA

Rosenau-Tornow D, Buchholz P, Riemann A, Wagner M (2009) Assessing long-term supply risks for mineral raw materialsa combined evaluation of past and future trends. Resour Pol $34: 161-175$

Safirova E (2013) The mineral industry of Russia. USGS 2011 Minerals yearbook. Washington DC, p 22

Scheele CW (1781) Tungstenens bestånds-delar, Kongliga Vetenskaps Academiens Nya Handlingar 2:89-95

Schubert WD, Lassner E (2010) ITIA Newsletter: 6. Cemented carbides, a success story. $\mathrm{p} 12$. International Tungsten Industry Association, 4 Heathfield Terrace, London W4 4JE, UK. http:// www.itia.info

Seddon M (2013) World tungsten report 2013, p 12, Metal Pages Ltd. mark@tungstenresearch.com, https://www.argusmedia.com/ / media/Files/PDFs/Samples/WorldTungsten_201311.pdf/?la=en

Senge P (1990) The fifth discipline. The art and practice of the learning organisation. Century Business, New York

Shedd KB (2003) Tungsten. US Geological Survey Minerals Yearbook-2003; 79.1-79.18

Shiyu Y (1991) Classification and type association of tin deposits in Southeast Yunnan Tin Belt. Chin J Geochem 10:21-35. doi:10.1007/BF02843295

Sterman JD (2000) Business dynamics, system thinking and modelling for a complex world. Irwin McGraw-Hill, New York

Sverdrup H (2016) Modelling global extraction, supply, price and depletion of the extractable geological resources with the LITHIUM model. Resour Conser Recycl 114:112-129

Sverdrup H, Ragnarsdottir KV (2014a) Natural resources in a planetary perspective. Geochem Perspect 3(2):129-341

Sverdrup HU, Ragnarsdottir KV (2014b) Natural Resources in a planetary perspective. Geochem Perspect 2(2):1-156

Sverdrup H, Ragnarsdottir KV (2016a) Modelling global extraction, supply, price and depletion of the extractable geological resources with the LITHIUM model. Resour Conserv Recycl 114:112-129

Sverdrup H, Ragnarsdottir KV (2016b) The future of platinum group metal supply; an integrated dynamic modelling for platinum group metal supply, reserves, stocks-in-use, market price and sustainability. Resour Conserv Recycl 114:130-152
Sverdrup H, Ragnarsdottir KV (2016c) Modelling the global primary extraction, supply, price and depletion of the extractable geological resources using the COBALT model. Biophys Econ Resour Quality

Sverdrup H, Ragnarsdottir KV (2016d) The future of platinum group metal supply: an integrated dynamic modelling for platinum group metal supply, reserves, stocks-in-use, market price and sustainability. Resour Conserv Recycl 114:130-152

Sverdrup H, Svensson M (2002) Defining sustainability. In: Developing principles for sustainable forestry, results from a research program in southern Sweden. Sverdrup H, Stjernquist I (eds) Managing forest ecosystems, vol 5. Kluwer Academic Publishers, Amsterdam, pp 21-32

Sverdrup H, Svensson M (2004) Defining the concept of sustainability, a matter of systems analysis. In: Olsson M, Sjöstedt G (eds) Revealing complex structures-challenges for Swedish systems analysis. Kluwer Academic Publishers, Amsterdam, pp 122-142

Sverdrup H, Ragnarsdottir KV, Koca D (2011) Challenging the planetary boundaries I: assessing the sustainable global population and phosphate supply, using a systems dynamics assessment model. Appl Geochem 26:S311-S313, doi:10.1016/j. apgeochem.2011.03.088

Sverdrup H, Koca D, Granath C (2012a) Modeling the gold market, explaining the past and assessing the physical and economical sustainability of future scenarios. In: Schwanninger M, Husemann E, Lane D (eds) Proceedings of the 30th International Conference of the System Dynamics Society. Model-based management. University of St. Gallen, Curran Associates, Inc., St. Gallen. Systems dynamics society 5:4002-4023. ISBN: 9781622764143

Sverdrup H, Koca D, Ragnarsdottir KV (2012b) The World 5 model; Peak metals, minerals, energy, wealth, food and population; urgent policy considerations for a sustainable society. In: Schwanninger M, Husemann E, Lane D (eds) Proceedings of the 30th International Conference of the System Dynamics Society. Curran Associates, Inc., St. Gallen. Model-based management 5:3975-4001, ISBN: 9781622764143

Sverdrup H, Koca D, Ragnarsdottir KV (2013) Peak metals, minerals, energy, wealth, food and population; urgent policy considerations for a sustainable society. J Earth Sci Eng 2:189

Sverdrup H, Koca D, Ragnarsdottir KV (2014a) Investigating the sustainability of the global silver supply, reserves, stocks in society and market price using different approaches. Resour Conserv Recycl 83:121-140

Sverdrup HU, Ragnarsdottir KV, Koca D (2014b) On modelling the global copper mining rates, market supply, copper price and the end of copper reserves. Resour Conserv Recycl 87:158-174

Sverdrup HU, Koca D, Ragnarsdottir KV (2015a) Aluminium for the future: modelling the global production, assessing long term supply to society and extraction of the global bauxite reserves. Resour Conserv Recycl 103:139-154

Sverdrup HU, Koca D, Ragnarsdottir KV (2015b) Defining a free market: drivers of unsustainability as illustrated with an example of shrimp farming in the mangrove forest in South East Asia. J Clean Prod 140:299-311. doi:10.1016/j.jclepro.2015.06.087

Sverdrup HU, Ragnarsdottir KV, Koca D (2017) An assessment of metal supply sustainability as an input to policy: security of supply extraction rates, stocks-in-use, recycling, and risk of scarcity. J Clean Prod 140:359-372. doi:10.1016/j.jclepro.2015.06.085

Tilton JE (2009) Is mineral depletion a threat to sustainable mining? Presented at international conference on sustainable mining, 17 Apr 2009, Santiago de Compostela, Spain

Tilton JE (2012) Is mineral depletion a threat to sustainable mining? Views III. Society of Economic Geologists Newsletter, vol 82

Tilton JE, Lagos G (2007) Assessing the long-run availability of copper. Resour Policy 32:19-23 
UNEP (2011a) Graedel TE, Allwood J, Birat JP, Reck BK, Sibley SF, Sonnemann G, Buchert M, Hagelüken C (eds) Recycling rates of metals-a status report, a report of the working group on the global metal flows to the International Resource Panel. UNEP, Nairobi, p 48

UNEP (2011b) The International Resource Panel. In: Graedel TE, Buchert M, Reck K, Sonnemann G (eds) Metal stocks in society; scientific synthesis. Recycling rates of metals: a status report. UNEP, Nairobi, p 32. ISBN: 978-92-807-3182-0

UNEP (2011c) In: Graedel TE (ed) Metal stocks in society-scientific synthesis, a report of the working group on the global metal flows to the International Resource Panel. UNEP, Nairobi, p 52

UNEP (2013a) In: Reuter M, Hudson C, Schalk A, Heiskanen K, Meskers C, Hagelüken C (eds) Metal recycling: opportunities, limits, infrastructure, a report of the working group on the global metal flows to the International Resource Panel. p 320. ISBN: 978-92-807-3267-2

UNEP (2013b) In: van der Voet E, Salminen R, Eckelman M, Mudd G, Norgate T, Hischier R (eds) Environmental risks and challenges of anthropogenic metals flows and cycles, a report of the working group on the global metal flows to the International Resource Panel, p 234. ISBN: 978-92-807-3266-5

UNEP (2013c) The International Resource Panel. In: Reuter M, Hudson C, Schalk A, Heiskanen K, Meskers C, Hagelüken C (eds) Metal recycling; opportunities, limits, infrastructure. UNEP, Nairobi. p 317. ISBN: 978-92-807-3167-2

US Department of the Interior, Bureau of Mines and Geological Survey (1980) Principles of a resource reserve classification for minerals. Geological Survey Circular 831, Washington DC
US Environmental Protection Agency (USEPA) (1994) Technical Resource Document Extraction and beneficiation of ores and minerals, p 127. EPA 530-R-94-011.

USGS (2009) United States Geological Survey, 2009, Mineral commodity summaries 2009: Appendix C, p 195

USGS (2015) Commodity Statistics for a Number of Metals (Consulted Several Times 2008-2015). United States Geological Survey. http://minerals.usgs.gov/minerals/pubs/commodity/. Accessed 2015

Visser W (2002) Tungsten production and consumption in the CIS, in Outlook for wolfram production and applications in the 21st century: International Wolfram Symposium, 9th, Pittsburgh, PA, September 30-October 4, 2002, presentation, p 22

Vulcan T (2013) Hard assets investor 2012. Rare metal rhenium's toughness under heat \& pressure key attraction as super-alloy \& turbine material. 6 p. http://www.hardassetsinvestor.com/ features/4666-rare-metal-rheniums-toughness-under-heat-apressure-key-attraction-as-super-alloy-a-turbine-material.html?s howall $=\&$ fullart $=1 \&$ start $=4$

Walser P (2002) World Tungsten mining activities, in Outlook for Wolfram Production and Applications in the 21st Century: International Wolfram Symposium, 9th, Pittsburgh, PA, September 30-October 4, 2002, presentation, p 69

Woodcock JT, Hamilton JK (eds) (1993) Australasian mining and metallurgy: the Sir Maurice Mawby memorial, vol 2. The Australasian Institute of Mining and Metallurgy, Melbourne 